\title{
PELATIHAN DIGITAL MARKETING BUMDES PENGELOLA OBJEK WISATA GOA LAUK DESA LEBAKTIPAR, LEBAK, BANTEN
}

\author{
Noor Falih ${ }^{1}$, Lukman Saleh Waluyo ${ }^{2}$ \\ Fakultas Ilmu Komputer, UPN Veteran Jakarta \\ Fakultas Ilmu Sosial dan Ilmu Politik, UPN Veteran Jakarta
}

\begin{abstract}
Abstrak
Komunikasi pemasaran adalah sarana di mana perusahaan berusaha menginformasikan, membujuk, dan mengingatkan konsumen secara langsung maupun tidak langsung tentang produk dan merek yang dijual. Komunikasi pemasaran mempresentasikan "suara" perusahaan dan mereknya serta merupakan sarana di mana perusahaan dapat membuat dialog dan membangun hubungan dengan konsumen. "Goa Lauk". Adalah Goa yang teletak di Desa Lebaktipar, kecamatan Cilograng kabupaten Lebak. Goa ini merupakan Goa yang memiliki ukuran besar dengan bentuk Goa bawah tanah yang dialiri oleh sungai bawah tanah yang berasal dari sungai sawarna. Goa ini telah lama menjadi bahan penelitian baik dari kalangan akademisi maupun ilmuwan, karena goa ini memiliki keunikan dan tekstur yang sangat indah, mulai dari keadaan alamnya, karangkarangnya dan segala ornamen yang terdapat di dalam goa tersebut. Selanjutnya setelah dilangsungkannya kegiatan ini, akan dilakukan secara kontinyu dengan mandiri oleh masyarakat pengelola objek wisata Goa Lauk untuk pengembangan kemampuan komunikasi pemasaran mereka. Adapun hasil dari kegiatan ini akan diperlihatkan dalam laporan terakhir.
\end{abstract}

Keywords: batik, cold wax, Betawi culture

\section{Pendahuluan}

Objek wisata merupakan bentuk desa yang memiliki ciri khusus di dalamnya, baik alam dan budaya, serta berpeluang dijadikan kunjungan bagi wisatawan. Wujud objek wisata itu sendiri bahwa desa sebagai objek dan subjek pariwisata. Sebagai objek merupakan tujuan kegiatan pariwisata, sedangkan sebagai subjek adalah sebagai penyelenggara, apa yang dihasilkan oleh desa akan dinikmati oleh masyarakatnya secara langsung dan peran aktif masyarakat sangat menentukan kelangsungan objek wisata itu sendiri. Banten merupakan salah satu provinsi dengan segudang potensi tujuan wisata yang menarik. Selain memiliki tempat tempat bersejarah yang menarik untuk dikunjungi, adat istiadat masyarakatnya pun sangat kental dengan nilai nilai historis yang unik untuk dipelajari. Upaya pengembangan objek wisata selain tempat tempat yang mengandung sejarah (historis) pengembangan pariwisata terbaru dilakukan dengan menyiapkan potensi potensi kampung kampung dan objek wisata. Provinsi Banten, sebenarnya memiliki banyak tempat tempat destinasi pariwisata terutama obyek wisata alam, sejarah dan kebuadayaan. Namun sayangnya masih sedikit sekali yang terkenal di kalangan para wisatawan dan masih terfokus hanya pada obyek obyek yang menjadi icon daerah tersebut. Salah satunya adalah Goa Lauk di Desa Lebaktipar, Sawarna Kabupaten Lebak. "Goa Lauk". Adalah Goa yang teletak di Desa Lebaktipar, kecamatan Cilograng kabupaten Lebak. Goa ini merupakan Goa yang memiliki ukuran besar dengan bentuk Goa bawah tanah yang dialiri oleh sungai bawah tanah yang berasal dari sungai sawarna. Goa ini telah lama menjadi bahan penelitian baik dari kalangan akademisi maupun ilmuwan, karena goa ini memiliki keunikan dan tekstur yang sangat indah, mulai dari keadaan alamnya, karang-karangnya dan segala ornamen yang terdapat di dalam goa tersebut. Apabila dipromosikan dengan memakai kegiatan promosi yang tepat, desa ini bisa menjadi salah satu objek wisata yang mampu bersaing dalam kegiatan industry pariwisata di Indonesia. Namun bagaimana cara pengelola untuk 
mempromosikan Objek Wisata Goa Lauk dalam menarik minat wisatawan, sedangkan pariwisata di Indonesia jumlahnya tidak sedikit. Salah satu usaha dalam mengembangkan pariwisata alternatif yang dapat memajukan pariwisata berdasarkan minat yang dimiliki oleh wisatawan itu sendiri. Belakangan ini banyak wisatawan yang cenderung memiliki minat khusus.

Menurut Pitana dan Diarta (2009:76) dalam bukunya Pengantar Ilmu Pariwisata dengan minat khusus 9 ini diperkirakan akan menjadi kemajuan perkembangan pariwisata ke depan sebab calon wisatawan telah menginginkan jenis pariwisata yang fokus, yang mampu memenuhi kebutuhan spesifik wisatawan. Segmen pasar semacam ini sangat senang dengan perbedaan-perbedaan produk yang mana megarah kepada perkembangan wisatawan yang memiliki minat khusus termaksud Objek Wisata Goa Lauk yang menawarkan produk, jasa dan pengalaman yang sangat luas. Pariwisata merupakan salah satu potensi sumber daya alam yang dapat dikembangkan oleh setiap daerah, sebagai salah satu sumber daya alam yang diharapkan bisa menghasilkan devisa bagi Negara. Indonesia merupakan Negara yang banyak memiliki keindahan alam yang melimpah, dan juga mempunyai daya tarik yang sangat mengagumkan. Selain itu juga menyumbangkan devisa bagi Negara, pariwisata juga mempunyai peran yang strategis dalam pembangunan nasional, yaitu: memperluas lapangan usaha, memperluas lapangan kerja, meningkatkan pendapatan masyarakat dan pemerintah, mendorong pelestarian dan pengembangan budaya bangsa, memperluas wawasan nusantara, mendorong perkembangan daerah, mendiring pelestarian lingkungan hidup, memperluas wawasan nusantara dan menumbuhkan rasa cinta tanah air. Seiring meningkatnya kebutuhan masyarakat untuk berwisata, Banten merupakan daerah yang banyak terdapat tujuan wisata yang diinginkan maka perlu adanya usaha pariwisata yang memungkinkan untuk dibuka dan di promosikan, belum ataupun kurang terolah dan sedapat mungkin dapat memberi dampak postif terhadap usaha yang dilakukan dengan basis kemasyarakatan. Sehingga selain memperkenalkan daerah tujuan wisata yang belum dikenal, tentu ini juga akan mempercepat terwujudnya pemerataan pendapatan dan kesempatan berusaha bagi masyarakat desa.

Dengan upaya pengelola dalam mempromosikan Objek wisata Goa Lauk, desa ini dapat menjadi objek wisata yang layak untuk di kunjungin oleh wisatawan dosmetik dan wisatawan mancanegara dan objek wisata ini dapat bersaing dengan pariwsiata lainnya di Indonesia. Beberapa upaya yang dilakukan oleh pihak pengelola Objek wisata Goa Lauk dalam mempromosikan sebagai objek wisata berupa promosi melalui media sosial yang termaksud ke dalam bagian dari kegiatan promosi. Objek wisata terebut merupakan destinasi wisata baru yang memiliki keunikan pesona alam indah berupa suasana, pemandangan, dan juga selain itu menurut hasil penelitian yang dilakukan oleh peneliti mengenai objek wisata Objek wisata Goa Lauk memiliki karakteristik khas yang berpotensi dikembangkan untuk menarik minat wisatawan. Wisatawan yang 10 berkunjung bisa belajar tentang alam, religi, dan sosial kemasyarakatan di desa ini oleh pemandu objek wisata sudah disediakan oleh pengelola Objek wisata Goa Lauk. Warga Masyarakat Desa Lebaktipar banyak menjadi pengelola objek wisata Goa Lauk, namun masih banyak dari mereka yang tidak mengetahui bagaimana cara praktik komunikasi pemasaran yang baik untuk menunjang pekerjaannya terutama dalam komunikasi pemasaran digital

\section{Metode}

Metode kegiatan PKM ini dengan menggunakan beragam metode pelatihan sebagai berikut: 1 . Ceramah Online Metode ini dipilih untuk menyampaikan konsep pelatihan digital marketing yang penting untuk dimengerti dan dikuasai oleh peserta dan cocok di tengah pandemi Covid-19 yang saat ini sedang berlangsung 2. Pembuatan Website Pemilihan metode ini bertujuan agar website dapat digunakan oleh Bumdes pengelola Goa Lauk. Website juga ditunjukkan saat mengunjungi Goa Lauk selain untuk pengambilan gambar dokumentasi untuk website 3. Preview, Evaluasi dan Tanya Jawab Metode ini digunakan sebagai acuan untuk menilai seberapa besar kemampuan pemahaman peserta terkait pelatihan digital marketing. Peserta akan diminta untuk melakukan praktek langsung 


\section{Hasil Dan Pembahasan}

Persiapan Bahan dan Instrumentasi Abdimas: Bahan dan Instrumentasi Abdimas yang kami gunakan adalah Laptop, Sewa Zoom, poster, formulir, pulsa peserta untuk pelatihan online, facebook ads, Narasumber tamu, Materi Bahan Abdimas, sertifikat untuk para peserta pelatihan. 2. Pelaksanaan abdimas dilaksanakan dua jenis. a. Jenis 1 yaitu pelatihan digital marketing online yang dilaksanakan pada hari 10 Juni 2020 - 22 Juli 2020, pada tahap ini dilakukan pelatihan digital marketing online kepada peserta Bumdes Cipta Daya Gemilang pengelola objek wisata Goa Lauk, memberikan penjelasan materi, pelatihan dan diskusi yang dipandu oleh Tim Abdimas. Pada pelatihan juga diberikan tugas praktik kepada peserta untuk dikerjakan. Materi dibawakan dengan jadwal setiap Rabu dengan materi: Digital Strategy, Web Development, Google Bisnisku, SEO, Facebook Ads, Influencer Marketing, Content Marketing, dan terakhir Google Ads b. Tahap 2 dilaksanakan secara offline tatap muka hari sabtu tanggal 5 September 2020. pada tahap ini adalah penunjukkan prototype website yang dibuat oleh tim abdimas kepada mitra, serta mengambil dokumentasi yang akan digunakan dalam pengembangan website. 3 . Tahapan Proses terselenggaranya pemaparan terkait dengan pelatihan dan pendampingan digital marketing a. Permohonan izin kepada mitra Bumdes Cipta Daya Gemilang b. Pencarian informasi terkait dengan Objek pengabdian yaitu Goa Lauk dan pengelolalnya, menyesuaikan kebutuhan yang sesuai dengan mereka c. Survei tempatlangsung di Desa Lebaktipar, Cilograng, Lebak, Banten

\section{Kesimpulan}

Terlaksananya kegiatan pengabdian kepada masyarakat ini yaitu pelatihan digital marketing dan pembuatan website kepada Bumdes Cipta Daya Gemilang pengelola Objek Wisata Goa Lauk, dapat dipahami bahwa mereka membutuhkan wadah pembelajaran mengenai digital marketing untuk menunjang segala kegiatan yang berhubungan dengan pekerjaan organisasinya. Hal ini dikarenakan selama ini terlaksananya kegiatan diketahui mereka belum optimal dalam penggunaan digital marketing. Diharapkan ke depan pelatihan dan website ini dapat menunjang promosi dari objek wisata Goa Lauk sehingga menambah nilai dan kemakmuran bagimasyarakat Desa Lebaktipar, Cilograng, Lebak, Banten.

\section{Saran}

Diperlukannya pendampingan dan pelaksanaan pendampingan lanjutan untuk para pengelola objek wisata Goa Lauk guna pelaksanaan kegiatan organisasi mereka yang berhubungan peningkatan ekonomi masyarakat. Maka dari itu perlu adanya kegiatan selanjutnya agar dapat meningkatkan nilai objek wisata Goa Lauk yang sesuai dengan harapan masyarakat dilingkungan Desa Lebaktipar itu sendiri.

\section{Daftar Pustaka}

Anik, Pamilu. 2007. Mengembangkan kreativitas dan kecerdasan anak. Jakarta: Buku kita Anggoro Gunawan, Generasi Millenial untuk Jakarta. Koran Kompas 21 Maret 2016https://nasional.sindonews.com/read/1388305/15/tiga-skills-diperlukan-untuk-hadapi-revolusiindustri-era-40-1553038602.

Chau, Clement, YouTube as a participatory culture, New Directions for Youth Development, vol 2010, issue 128.

Downing, Kris, Next Generation; what leaders need to know about the millenials, Leadership in action, 2006.

Flew, Terry. An Introduction; New Media. 2002. Oxford Press. 
Postigo, Hector, The socio-technical architecture of digital labor: Converting play into YouTube money, New Media and Society 2014.

Straubhaar and La Rose. Media Now; 2014. SAGE Publication.

Yeni Rahmawati. 2005. Strategi Pengembangan kreativitas pada anak usia taman kanakkanak. Djogjakarta: Panduan Jala Sutra 